\title{
Phytochemical study and antiulcerogenic activity of Syngonanthus bisulcatus (Eriocaulaceae)
}

\author{
Roberta Gomes Coelho ${ }^{1 *}$, Leônia Maria Batista ${ }^{2,3}$, Lourdes Campaner dos Santos ${ }^{1}$, Alba Regina \\ Monteiro de Souza Brito ${ }^{2}$, Wagner Vilegas ${ }^{1}$
} ${ }^{1}$ Departamento de Química Orgânica, Instituto de Química de Araraquara, UNESP, ${ }^{2}$ Departamento de Fisiologia e
Biofísica, IB/UNICAMP, ${ }^{3}$ Departamento de Ciências Farmacêtuticas, CCS, UFPB, Paraíba

*Correspondence:

R. G. Coelho

Instituto de Química - UNESP

Rua Francisco Degni, s/n

Quitandinha

14800-900 - Araraquara, SP, Brasil

Email: robecoel@posgrad.iq.unesp.br
From the ethanol extract of the capitula and scapes of Syngonanthus bisulcatus (Koern) Ruhland the flavonoids 5-hydroxy-7,4'dimethoxy-6-C- $\beta$-D-glucopyranosylflavone, isovitexin $\left(5,7,4^{\prime}\right.$ 'trihydroxy-6-C- $\beta$-D-glucopyranosylflavone), luteolin $\left(5,7,3^{\prime}, 4^{\prime}\right.$ 'tetrahydroxyflavone), lutonarin $\left(5,3^{\prime}, 4^{\prime}\right.$-trihydroxy-6-C-7-O- $\beta$ - $D$ glucopyranosylflavone) and 5,6,3',4'-tetrahydroxy-7-O- $\beta$-Dglucopyrade were isolated. The structure of the compounds were characterized by spectroscopic methods, mainly $1 D$ and $2 D N M R$ experiments, as well as ESMS spectrometry. In addition we examined the effect of the ethanol extract of capitulae and scapes in the ulcer model ethanol/HCl-induced gastric mucosal lesions.

\section{Uniterms}

- Syngonanthus bisulcatus

- Antiulcerogenic activity

- Flavonoids

\section{INTRODUCTION}

"Sempre-vivas" (everlasting plants) is the name given in Brazil to some plants whose inflorescences and scapes conserve the appearance of the living structures even after being dried when harvested out. They are sold locally and exported for ornamental purposes (Giullietti et al., 1996). Most of these plants belong to the Syngonanthus genus (Eriocaulaceae). Until recently, the knowledge about the flavonoids chemistry of the Syngonanthus Ruhl. genus was limited to the paper of Ricci et al. (1996), who reported the presence of apigenin and luteolin derivatives in the leaves of some species.

Flavonoids encompass a large group of polyphenolic substances that has antibacterial, antiinflammatory, antiallergic, antimutagenic, antiviral, antineoplastic, and vasodilator effects. Several studies related to be potent antioxidants, capable of scavenging hydroxyl radical, super oxide anions and lipid peroxy radicals (Miller, 1996).

The peptic ulcers are illnesses that affect a considerable number of people in the world. They are induced by stress, smoking, nutritional deficiencies and ingestion of non-steroidal-anti-inflammatory drugs (Nash et al., 1984; Basil et al., 1995). The etiology of ulcer is still unknown. It is generally accepted that it results from an imbalance between aggressive factors such as acid and pepsin and the maintenance of mucosal integrity through endogenous defense mechanisms (Wallace et al., 1996).

Different therapeutic agents, including plant extract containing flavonoids, are used to inhibit gastric acid secretion or to boost mucosal defense mechanisms have been shown to produce promising results for the treatment of gastric ulcers (Vilegas et al., 1998).

Therefore, in order to investigate the possible antiulcerogenic activity and to contribute to the chemical 
study of Syngonanthus we have examined ethanol extracts capitula and the scapes of $S$. bisulcatus (Koern) Ruhland. This flower is know as "sempre-viva chapadeira". It occurs mainly in Southeast region of Brazil, at Serra do Cipó and Diamantina - Minas Gerais State, and several tons are exported to many developed countries.

\section{MATERIAL AND METHODS}

\section{Plant Material}

The specimen were collected at Serra do Cipó State Minas Gerais - Brazil and identified by Paulo Takeo Sano. Voucher specimen was deposited at the Herbarium of Departamento de Botânica do Instituto de Biociências - Universidade de São Paulo (SPF77735).

\section{Extraction and preparation of ethanolic extracts}

Capitula (280 g) and scapes (300 g) were separated, dried in an oven at $45^{\circ} \mathrm{C}$ for 1 week and powdered. The resulting materials were separately macerated at room temperature sequentially with hexane, methylene chloride and ethanol for 1 week with each solvent. Extracts were filtered and concentrated under vacuum affording the hexane $(1.2 \mathrm{~g})$ methylene chloride $(2.7 \mathrm{~g})$ and ethanol $(6.0 \mathrm{~g})$ extracts of the capitula and scapes. For this work we used only ethanol extract from capitula and scapes.

\section{Animals}

Male Swiss albino mice (25-35g) from the Central animal House of Universidade Estadual de Campinas (CEMIB/UNICAMP) were used. The animal were fed a certified Nuvilab CR-a (Nuvital) diet with free access to water under standard conditions of $12 \mathrm{~h}$ dark $12 \mathrm{~h}$ light period, humidity $(60 \pm 1.0 \%)$ and temperature $(21.5 \pm 1.0 \%)$. The experimental protocols were approved by the institutional (UNICAMP) Animal Care and Use Committee, in accordance with the recommendations of the Canadian Council for Animal Care (Olfert et al., 1993; Zimmermann, 1983), protocol number 502 .

\section{Drugs}

The following drugs were used: saline solution $0.9 \%$, lanzoprazole, ethanol $60 \%$ and $\mathrm{HCl} 0.3 \mathrm{M}$. All reagents were of a high grade of purity. The substances and reagents were prepared immediately before use.

\section{Isolation and identification of the flavonoids (1-5)}

$1.5 \mathrm{~g}$ of ethanol extracts were fractionated by gel permeation Column Chromatography (Sephadex LH20, Pharmacia) eluted with methanol. The substances obtained were further purified by repeated Column Chromatography either on polyvinypolypyrrolidone (Sigma, eluted with $\mathrm{MeOH}$ ) or on RP 18 column (Lichroprep. RP18 - Merck, 40-63 mm) eluted with acetonitrile/water 85:15 (v/v) and 70:30 (v/v). The structures of the flavonoids 1-5 were unambiguously determined by means of spectroscopic methods (IR, ESMS, ${ }^{1} \mathrm{H},{ }^{13} \mathrm{C}$ and $2 \mathrm{D}$ NMR experiments COSY, HSQC, HMBC) and compared to those previously reported (Agrawal, 1989; Harborne, 1996; Markham,1982).

\section{Antiulcerogenic Activity}

\section{Ethanol/HCl - Induced Gastric Mucosal Lesions}

The anti-ulcerogenic activity of ethanol extracts obtained from the capitula and scapes of Syngonanthus bisulcatus after ulcer induction with ethanol/ $\mathrm{HCl}$ was performed according to the method of Mizui and Doteuchi (Mizui, Douteuchi, 1983) with some modifications. Mice were fasted for $24 \mathrm{~h}$, divided into groups of 7 animals and before receiving an oral dose of vehicle (saline solution $0.9 \%$ ), lanzoprazole $(30 \mathrm{mg} /$ $\mathrm{kg}$ ) and the Syngonanthus bisulcatus ethanolic extracts $(50,100$ and $250 \mathrm{mg} / \mathrm{kg})$. Fifty minutes after the treatments, all groups received $0.2 \mathrm{ml}$ of $0.3 \mathrm{M} \mathrm{HCl} /$ $60 \%$ ethanol solution orally.

Animals were killed $1 \mathrm{~h}$ after the administration of $\mathrm{HCl} / \mathrm{EtOH}$ solution; the stomachs were excised, inflated by an injection of saline $(2 \mathrm{ml})$ and opened along the greater curvature. Then the stomachs were fixed and the ulcerative lesion index (ULI) calculated according to the methodology described by Szelenyi and Thiemer (1978).

The lesion index was expressed as the sum of all lesions. Results are expressed as an ulcerative index (UI) as described by Szelenyi and Thiemer (1978).

\section{Statistical analysis}

Results were expressed as the mean \pm S.E. Statistical significance between groups was determined by one way analysis of variance (ANOVA) followed by Dunnett's test, with the level of significance set at $p<0.05$ or $p<0.001$. 


\section{RESULTS AND DISCUSSION}

The effect of ethanol extracts of Syngonanthus bisulcatus on ethanol/ $\mathrm{HCl}$ gastric ulcers was investigated in mice. The results of the present study are summarized in Table 1.

Oral administration of ethanol/ $\mathrm{HCl}$ solution to the control group clearly produced the expected characteristic zonal necrotizing mucosal lesion. The lanzoprazole and ethanolic extracts obtained from the capitula and scapes of Syngonanthus bisulcatus (50, 100, $250 \mathrm{mg} / \mathrm{kg}$ ) significantly inhibited the ulcer formation when compared with control group.

The oral treatment of mice with ethanol, induces solubilization of mucus constituents in the stomach with a concomitant fall in the transmucosal potential difference.

This agent also increases $\mathrm{Na}^{+}$and $\mathrm{K}^{+}$flux into the lumen and increases histamine release and pepsin. It also depresses tissue levels of DNA, RNA and proteins, leading to flow, stasis in injured tissue (Szabo, 1987). The ethanol induces the formation of gastric ulcers and the presence of $\mathrm{HCl}$ only accelerates the process (Sun et al., 1991).

The damage may be due to stasis in gastric blood flow which contributes to the development of the hemorrhage and necrotic aspects of tissue injury (Guth et al., 1984). This action is direct on the gastric epithelium also causing perturbation of mast cells and release of a vasoative mediator such as histamine (Oates et al., 1988).

In order to identify some compounds present in the active fractions we have performed a chromatographic fractionation of the ethanol extracts of capitula and scapes that led to the isolation of compounds $\mathbf{1 - 5}$. When revealed with NP-PEG reagent, these compounds showed yellow or orange spots characteristic of flavonoids (Wagner et al., 1984). The extract of capitulae afforded two apigenin derivatives: 5 -hydroxy-7,4'-dimethoxy-6- $C$ - $\beta$-Dglucopyranosylflavone $\mathbf{1}$ (200 mg), and 5,7,4'-trihydroxy$6-C$ - $\beta$-D-glucopyranosylflavone $2(300 \mathrm{mg})$. The extract of scapes afforded three luteolin derivatives: 5,7,3',4'tetrahydroxyflavone 3 (150 mg), 5,3',4'-trihydroxy-6-C$7-O-\beta$-D-glucopyranosylflavone $4(200 \mathrm{mg})$, and $5,6,3^{\prime}, 4^{\prime}$-tetrahydroxy-7-O- $\beta$-D-glucopyranosylflavone 5 (250 mg) (Figure 1). These compounds were determined by comparison of their ${ }^{1} \mathrm{H}$ and ${ }^{13} \mathrm{C}$ NMR, IR, UV and ESMS data with those previously reported (Harborne, 1996; Agrawal, 1984; Markham, 1982).

Our results suggests a more complex flavonoid pattern for Syngonanthus bisulcatus than that previously reported by Ricci (1996) for the leaves of Syngonanthus xeranthemoids and Syngonanthus verticillatus, since capitula present apigenin- $C$-glycosides whereas scapes present luteolin $O$ - and $C$-glycosides (Harborne, 1996).

Ethanol-induced gastric lesion are thought to arise as a result of direct damage of gastric mucosal cells, resulting in the development of free radicals (Pihan et al., 1987) and hyperoxidation of lipids (Purunen et al., 1980). Literature reports that flavonoids can act as antiulcer compounds probably because of their antioxidant properties, that could prevent the formation of free radicals in the body and also minimize injuries by oxidative reactions (La Casa, 2000). Besides, compounds that have a cathecolic system, such as the ring B of luteolin

TABLE I - Effects of lanzoprazole and different doses of ethanolic extracts of Syngonanthus bisulcatus on model HCl/ ethanol-induced gastric ulcer in mice.

\begin{tabular}{lcccc}
\hline $\begin{array}{l}\text { Ulcerative } \\
\text { Model }\end{array}$ & $\begin{array}{c}\text { Treatment } \\
\text { (p.o.) }\end{array}$ & $\begin{array}{c}\text { Dose } \\
(\mathrm{mg} / \mathrm{kg} \text { body wt) }\end{array}$ & $\begin{array}{c}\text { Ulcerative Index } \\
(\mathrm{mm})\end{array}$ & $\begin{array}{c}\text { Inhibition } \\
(\%)\end{array}$ \\
\hline Ethanol /HCl & Saline & - & $77 \pm 20$ & 0 \\
& Lanzoprazole & 30 & $25 \pm 13^{*}$ & 67 \\
& EtOH (capitula) & 50 & $34 \pm 14^{*}$ & 56 \\
& EtOH (capitula) & 100 & $32 \pm 10^{*}$ & 58 \\
& EtOH (capitula) & 250 & $30 \pm 14^{*}$ & 61 \\
Ethanol/HCl & & & & \\
& Saline & - & $46 \pm 21$ & 0 \\
& Lanzoprazole & 30 & $20 \pm 8.3^{*}$ & 57 \\
& EtOH (scapes) & 50 & $17 \pm 6.5^{*}$ & 63 \\
& EtOH (scapes) & 100 & $17 \pm 7.1^{*}$ & 63 \\
& EtOH (scapes) & -250 & $11 \pm 4.6^{*}$ & 76 \\
\hline
\end{tabular}

The results are expressed as mean \pm S.E. Data were always calculated in relation to the respective control group. ANOVA: $\mathrm{F}_{(4.25)}=4.2 \mathrm{p}<0.05$. Dunnett's test $* \mathrm{p}<0.05$. 

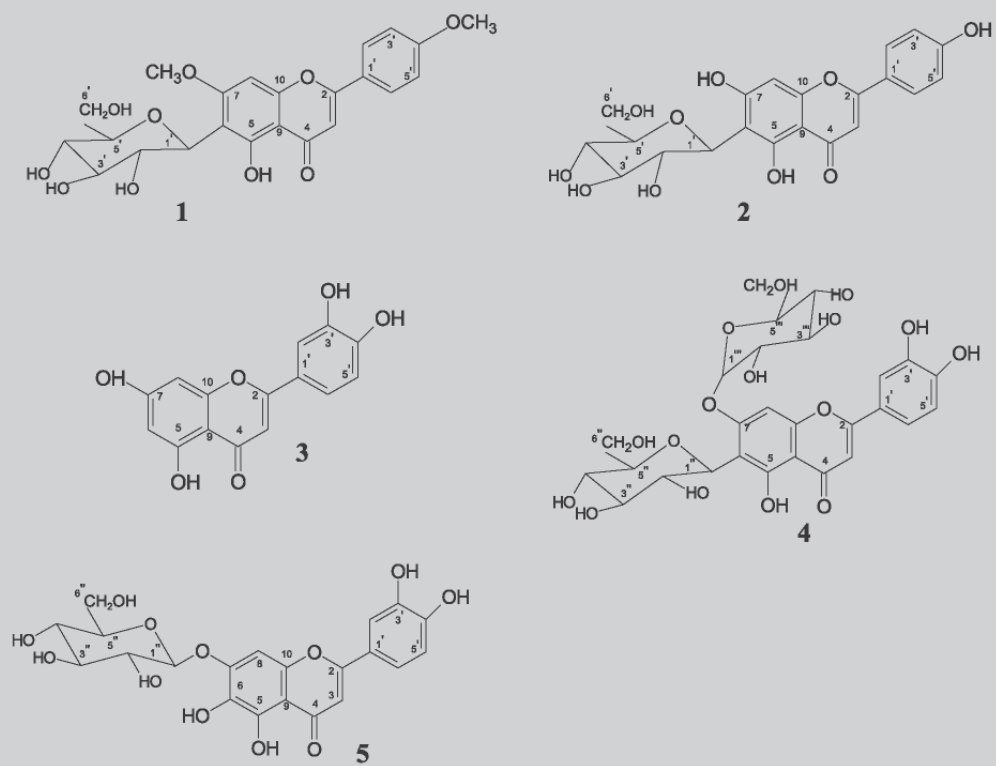

Figure 1 - Flavonoids isolated of the ethanolic extract from the capitula and scapes of Syngonanthus bisulcatus.

derivatives, have presented antioxidant and antiulcer activities (Yesildada et al., 2000).

Phytochemical and pharmacological studies have sugested that flavonoids present in the ethanolic extracts obtained from the Syngonanthus bisulcatus may be regarded as possible active compounds against gastric lesions probably due their antisecretory and cytoprotector effects. Further analyses and experiments with the isolated flavonoids will be performed in a near future to check these hypothesis.

\section{ACKNOWLEDGEMENTS}

We thank to Fundação de Amparo à Pesquisa do Estado de São Paulo (FAPESP) for grant to R.G.C and to CNPq for a grant given to W.V and L.M.B. We also thank Lara Regina Parra and Paulo Takeo Sano ( Departamento de Botânica do Instituto de Biociências - Universidade de São Paulo) for the identification of S. bisulcatus.

\section{RESUMO}

\section{Estudo Fitoquímico e Atividade Antiulcerogênica de Syngonanthus bisulcatus (Eriocaulaceae)}

Do extrato etanólico dos capitulos e dos escapos de Syngonanthus bisulcatus (Koern) Ruhland foram isolados os flavonóides: 5-hidroxi-7,4'-dimetoxi-6-C- $\beta$ - $D$ glicopiranosilflavona, isovitexina (5,7,4'-triidróxi-6-C$\beta$-D-glicopiranosilflavona, luteolina (5,7,3',4'- tetraidroxiflavona), lutonarina (5,3',4'-triidroxi-6-C-7O- $\beta$-D-glicopiranosilflavona) e 5,6,3',4'-tetraidroxi-7O- $\beta$-D-glicopiranosilflavona. As estruturas dos compostos foram caracterizadas por espectroscopia (RMN mono e bi-dimensionais) e por espectrometria de massas Electrospray. Adicionalmente foram examinados os efeitos dos extratos etanólicos dos capitulos e dos escapos pelo modelo de úlcera induzida por etanol/HCl

UNITERMOS: Syngonanthus bisulcatus. Atividade antiulcerôgenica. Flavonóides.

\section{REFERENCES}

AGRAWAL, P.K. Carbon 13 NMR of flavonoids. Amsterdam: Elsevier, 1989. 564p.

BASIL, M.D.; HOWARD, M.S. Clinical gastroenterology. 4th ed. New York: Mc-Graw-Hill, 1995. p.113-161.

GIULLIETTI, A.M.; WANDERLEY, M.G. L.; PIRANI, J.R.; PARRA, L.R. Estudos em sempre-vivas: taxonomia com ênfase nas espécies de Minas Gerais, Brasil. Acta. Bot. Bras., v. 10, p.329-377, 1996.

GUTH, P.H.; PAULSEN, G.; NAGATA, H. Histologic and microcirculatory changes in alcohol-induced gastriclesions in the rat-effect of prostaglandin cytoprotection Gastroenterol., v.87, n.5, p.1083-1090, 1984. 
HARBORNE, J.B. The Flavonoids advances in research since 1986. London: Chapman and Hall, 1996. 675p.

LA CASA, I.; VILLEGAS, C.; ALARCÓN DE LA LASTRA, V.; MOTILVA, M. J.; MÁRTIN, C. Evidence for protective and antioxidant properties of rutin, a natural flavone, against ethanol induced gastric lesions. $J$. Ethnopharmacol., v.71, n.1-2, p.45-53, 2000.

MARKHAM, K.R. Techniques offlavonoids identification. London: Academic Press, 1982. 113p.

MILLER, A.L. Antioxidant flavonoids: structure, function and clinical usage. Altern. Med. Rev., v.1, n.2, p.103-111, 1996.

MIZUI, T.; DOUTEUCHI, M. Effect of polyamines on acidified ethanol gastric-lesions in rats. J. Pharmacol., v.33, n.5, p.939-945, 1983.

NASH, J.; LAMBERT, L.; DEAKIN, M. Histamine h-2receptor antagonists in peptic-ulcer disease - evidence for a prophylactic use. Drugs, v.47, p.862-871, 1984.

OLFERT, E.D; CROSS, B.M.; MCWILLIAM, A.A. Guide to the care and use of experimental animals. In: OLFERT, E.D.; CROSS, B.M.; McWilliam, A.A. (Eds.) Canadian Council on Animal Care. Ottawa, Ontario: Saskatoon, Saskatchewan, 1993. v.1, p. 213.

OATES, P.J.; HAKKINEN, J.P. Studies on the mechanism of ethanol-induced gastric damage in rats. Gastroenterol., v.94, p.10-21, 1988.

PIHAN, G.; REGILL, C.; SZABO, S. Free-radicals and lipidperoxidation in ethanol-induced or aspirin-induced gastric-mucosal injury. Dis. Sc., v.32, p.1395-1401, 1987.

PUURUNEN, J.; HUTTUNEN, P.; HIRVONEN, J. Is ethanol-induced damage of the gastric-mucosa a hyperosmotic effect - comparative studies on the effects of ethanol, some other hyperosmotic solutions and acetylsalicylic-acid on rat gastric-mucosa. Acta Pharmacol. Toxicol., v.47, n.5, p.321-327, 1980.

RICCI, C.V.; PATRÍCIO, M.C.B.; SALATINO, M.L.F.; SALATINO, A.; GIULIETTI, A.M. Flavonoids of Syngonanthus Ruhl (Eriocaulaceae): taxonomic implications. Biochem. System. Ecol., v.24, n.6, p.577583, 1996.
SOUZA-FORMIGONI, M.L.O.; OLIVEIRA, M.G.M.; MONTEIRO, M.G.; FILHO, N.G.S.; BRAZ, S.; CARLINI, E.A. Antiulcerogenic effects of 2 Maytenus species in laboratory-animals. J. Ethnopharmacol., v.34, n.1, p.21-27, 1991.

SUN, S.B.; MATSUMOTO, T.; YAMADA, H. Effects of a polysaccharide fraction from the roots of Bupleurum falcatum $\mathrm{L}$. on experimental gastric ulcer models in rats and mice J. Pharm. Pharmacol., v.43, p.699-704, 1991.

SZABO, S. Mechanisms of mucosal injury in the stomach and duodenum-time-sequence analysis of morphological, functional, biochemical and histochemical-studies. Scand. J. Gastroenterol., v.22, p.21-28, 1987.

SZELENYI, I.; THIEMER, K. Distention ulcer as a model for testing of drugs for ulcerogenic side-effects. Arch. Toxicol., v.41, p.99-105, 1978.

VILEGAS, W.; SANOMMIYA, M.; RASTRELLI, L.; PIZZA, C. Isolation and structure elucidation of two new flavonoid glycosides from the infusion of Maytenus aquifolium leaves. evaluation of the antiulcer activity of the infusion J.Agric. Food Chem., v.47, p.403-406, 1998.

WAGNER, H.M.; BLADT, S.; ZGAINSKI, E.M. Plant drug analysis. New York: Springer-Verlag, 1984. 320p.

WALLACE, J.L.; GRANGER. D.N. The cellular and molecular basis of gastric mucosal defense. FASEB J., v.10, n.7, p.731-740, 1996.

YESILADA, E., TSUCHIYA, K., TAKAISHI, Y., KAWAZOE, K. Isolation and characterization of free radical scavenging flavonoid glycosides from the flowers of Spartium junceum by activity-guided fractionation. $J$. Ethnopharmacol., v.73, n.3, p.471-478, 2000.

ZIMMERMANN, M. Ethical guidelines for investigations of experimental pain in conscious animals. Pain v. 16, 109110, 1983.

Recebido para publicação em 15 de junho de 2005. Aceito para publicação em 24 de maio de 2006. 